\title{
Hypertension in Autosomal Dominant Polycystic Kidney Disease: A Meta-Analysis
}

\section{Matko Marlais', Oliver Cuthell ${ }^{2}$, Dean Langan', Jan Dudley², Manish D Sinha $^{3}$, Paul JD Winyard ${ }^{1}$}

(1) Institute of Child Health, University College London, London

(2) University Hospitals Bristol NHS Foundation Trust, Bristol

(3) Evelina London Children's Hospital, London

Keywords: paediatrics, polycystic kidney disease, blood pressure

Address for Correspondence:

Professor Paul Winyard

Institute of Child Health

University College London

30 Guilford Street

London, WC1N 1EH

p.winyard@ucl.ac.uk

Abstract Word Count: 260 words

Word Count: 2965 words (excluding title page, abstract, headings, tables, figures, references) 


\section{Abstract}

Context: Autosomal Dominant Polycystic Kidney Disease (ADPKD) is a common disorder that can cause hypertension during childhood, but the true prevalence of hypertension during childhood is not known.

Objective: We undertook a systematic review and meta-analysis to determine the prevalence of hypertension in children with ADPKD.

Data Sources: Systematic review of articles published between 1980-2015 in MEDLINE and EMBASE.

Study Selection: Studies selected by 2 authors independently if reporting data on prevalence of hypertension in children and young persons aged $<21$ years with a diagnosis of ADPKD. Observational series were included with study populations $>15$ children. Articles excluded if inadequate diagnostic criteria for hypertension were used. Studies with selection bias were included but analysed separately

Data Extraction: Data extracted on prevalence of hypertension, proteinuria and reduced renal function using standardised form. Meta-analysis was performed to calculate weighted mean prevalence.

Results: 903 articles were retrieved from our search; 14 studies met the inclusion criteria: 1 prospective randomised controlled trial; 8 prospective observational studies; and 5 retrospective cross-sectional studies. From 928 children with clinically confirmed 
ADPKD, 20\% [95\% Cl 15-27\%] were hypertensive. The estimated prevalence of proteinuria in children with ADPKD is $20 \%$ [8 studies; $95 \% \mathrm{CI} 9-40 \%$ ] while reduced renal function occurred in $8 \%$ [5 studies; 95\% Cl 2-26\%].

Limitations: Studies showed a high degree of methodological heterogeneity $\left(I^{2}=\right.$ $\left.73.4 \%, \tau^{2}=0.3408, \mathrm{p}<0.0001\right)$. Most studies did not use ABPM to diagnose hypertension.

Conclusions: In this meta-analysis we estimate $20 \%$ of children with ADPKD have hypertension. In the population, many children with ADPKD are not under regular follow up and remain undiagnosed. We recommend that all children at risk of ADPKD have regular BP measurement. 


\section{Introduction}

Autosomal dominant polycystic kidney disease (ADPKD) is a common genetic disease affecting around 1:1000 individuals.[1] Two thirds of patients are hypertensive by the age of 30 , but most are easily managed with a single antihypertensive agent in the early stages. In adults there is evidence that intensive blood pressure control can result in favourable clinical endpoints, and untreated hypertension can lead to an increased risk of death from cardiovascular causes.[2] There is also evidence in children with ADPKD that borderline hypertension can cause an increased left ventricular mass,[3] reinforcing the need for good BP control.

There is a lack of consensus with regard to optimal timing of initiation of BP monitoring in children with ADPKD. The data that is available on ADPKD symptoms and signs in children is limited, but a striking feature is the high prevalence of hypertension with several studies reporting between $30-40 \%$.[3-5] The risk of hypertension in children with ADPKD is uncertain because there have been a number of different reports with varying rates of hypertension, often from relatively small study populations.

The primary aim of this study was to determine the prevalence of hypertension in children and young persons with ADPKD, via a systematic review and meta-analysis of current literature. Secondary aims were to determine the prevalence of proteinuria, an early indicator of disease in many renal conditions, and impaired renal function as a later sign of $A D P K D$ progression.

\section{Methods}




\section{Eligibility Criteria}

Studies considered eligible for inclusion in this systematic review were those reporting data on the prevalence of hypertension children and young people ( $<21$ years) with a confirmed diagnosis of ADPKD. All study designs were considered if they reported data on a minimum of 15 children, including retrospective and observational studies. Studies were included even if their primary aim was not to establish the prevalence of hypertension in children with ADPKD.

Studies were excluded if they did not report specific data on the prevalence of hypertension in children with ADPKD. Studies were excluded if they did not report adequate diagnostic criteria for ADPKD. Adequate diagnostic criteria would be considered as the presence of renal cysts seen on ultrasound with a positive family history of ADPKD and/or genetic confirmation of ADPKD. Studies were excluded if they were of insufficient methodological quality. Studies were also excluded if they did not use an appropriate diagnostic definition for hypertension, according to national/international guidance a definition of $>95^{\text {th }}$ blood pressure centile for age and gender was required (additionally those on treatment for hypertension were classed as hypertensive).[6] Studies were excluded if they were duplicate publications or clearly contained the same study population as another published study already included in this review. Where this was the case the study with the largest number of participants was included in this review. Articles not published in English were excluded. 


\section{Information Sources, Search and Study Selection}

A systematic search was undertaken searching the MEDLINE and EMBASE databases for published articles (excluding any published abstracts) from 1980-2015. The search was last conducted in July 2015. The search strategy is in Supplemental File 1.

The titles of all papers retrieved from this search were screened by two authors (MM and $\mathrm{OC}$ ) independently for potential inclusion in this review. Potentially relevant studies were reviewed (full-text) for inclusion according to the eligibility criteria. Final study selection was undertaken by two authors (MM and PW). Reference lists of included studies were additionally reviewed for potentially relevant articles. Data extracted from studies was included in the meta-analysis.

\section{Data Collection Process and Data Items}

Data were collected from included studies using a standardised proforma, piloted by one author (MM) and subsequently improved to include data on additional outcomes. Data extracted included study year, study setting, number of children with ADPKD, study design, primary aim of the study and method of recruitment/selection of children into the study (to establish risk of selection bias). Data were also collected on the prevalence of hypertension, proteinuria and impaired renal function. Proteinuria was defined by the local measurement method but only studies reporting laboratory 
confirmed proteinuria according to international standards were included in this analysis (dipstick confirmation was not accepted). Impaired renal function was taken as a GFR (actual or estimated) as $<90 \mathrm{ml} / \mathrm{min} / 1.73 \mathrm{~m}^{2}$.

\section{Risk of Bias in Included Studies}

Although there are many tools which can be used to assess observational studies in epidemiology as detailed in the review by Sanderson et al,[7] we are not aware of any widely used quality assessment tool for prevalence studies and as different study designs were included in this review, we devised a study qualitative evaluation method specifically for this review. Included studies were all reviewed in detail and assigned a risk of selection bias score (low/moderate/high) as this is one of the main flaws of previously published studies reporting the prevalence of hypertension in children with ADPKD. Quality markers for each study are defined in Supplementary File 2 and each study was ascribed a score of $0-5$ based on the presence of these five markers.

\section{Summary Measures and Synthesis of Results}

The proportion of children with ADPKD who are hypertensive for each study is reported, this was combined in a random-effects meta-analysis to obtain a mean prevalence for hypertension (with 95\% confidence intervals and prediction intervals). Prevalence was converted to the logit-scale for data synthesis and back-transformed. 
Restricted maximum likelihood (REML) was used to estimate the heterogeneity variance. Study qualitative evaluation score was not included in the weighting but separate meta-analysis has been performed for studies based on the risk of selection bias.

\section{Risk of Bias across Studies}

We assessed the risk of bias across studies by presenting a funnel plot (prevalence of hypertension plotted against study size) to determine whether the study data was skewed.

\section{Additional Analyses}

We analysed whether there was a relationship between prevalence of hypertension and prevalence of proteinuria in children with ADPKD at study level. We also analysed whether there was a relationship between the mean age of children in a study and prevalence of hypertension in the study.

Results are depicted graphically and study-level data analysed using Spearman's rank correlation coefficient to assess for statistical significance. Two-tailed testing was used 
and a $p$-value of $<0.05$ was considered statistically significant. Statistical testing was performed using SPSS version 21.

We ran two meta-regression models to test whether there was a relationship between prevalence of hypertension and (1) prevalence of proteinuria in children with ADPKD and (2) mean age of children at the study level. It was not appropriate to test for an association with prevalence of reduced GFR because of the extent of missing data.

Results are depicted graphically using bubble plots. Parameter estimates from the meta-regression models, confidence intervals and $p$-values are presented.

All statistical tests were two-tailed and a $p$-value of $<0.05$ was considered statistically significant. Statistical analysis was performed using Rstudio (R version 3.2.2), mainly using the functions metaprop and metareg (in package meta). 


\section{Results}

\section{Study Selection and Characteristics}

The initial search retrieved records for 903 published articles. 90 full text articles were retrieved after an initial screen of titles. 29 studies were assessed in detail for potential inclusion in this systematic review (Supplementary File 3).

5 studies were excluded because they did not report the proportion of children that were hypertensive, or they did not separate this data for children and adults. 3 studies were excluded due to insufficient quality or reporting data for $<15$ children. 7 studies were excluded as they were duplicate publications or using the same population of children with ADPKD as another included study.

14 studies were eligible for inclusion in this review, Table 1 contains their details. 5 studies were from the USA, 2 from Canada, 2 from France, 2 from the Czech Republic and 1 study each from the UK, Spain and Cyprus. 1 study was a randomised-controlled trial, 8 were prospective observational studies while 5 were retrospective cohort or cross-sectional studies. None of the studies had the primary aim of determining the prevalence of hypertension in children with ADPKD, but only one study had missing hypertension data of more than $20 \%$ for children included in that study. Only 1 study used 24 hour ambulatory BP measurement (ABPM) to diagnose hypertension in all children with ADPKD.

\section{Risk of Bias}


Supplementary File 4 shows a table reporting the risk of selection bias for each study and the quality evaluation. Three studies had a high risk of selection bias. The data is skewed in the funnel plot (Supplementary File 5) with larger studies reporting a higher prevalence of hypertension than smaller studies. This cannot be interpreted as publication bias, given that none of the studies have the primary aim of documenting the prevalence of hypertension and that we excluded studies not reporting data on hypertension, but the skew is noted. All excluded studies which report study populations of children with ADPKD but do not include BP data were relatively small.

\section{Primary Outcome}

Table 2 shows the results of individual studies. The primary outcome of prevalence of hypertension is also depicted in the forest plot in Figure 1 (studies grouped according to risk of bias assessment), showing that the weighted mean prevalence of hypertension in 928 children with ADPKD is $20 \%$ [95\% Cl $15-27 \%]$. Heterogeneity accounted for most of the variation in study prevalence $\left(I^{2}=73.4 \%, \tau^{2}=0.3408\right.$, $p<0.0001)$. Given the level of heterogeneity, the prediction interval is much wider than the confidence interval [95\%PI 6-50\%].

When the three studies with a high risk of selection bias are removed from the analysis, the weighted mean prevalence of hypertension in children with ADPKD across 11 studies $(769$ children) is virtually unchanged at $20 \%[95 \% \mathrm{Cl} 14-27 \%]$ and there is still high heterogeneity $\left(I^{2}=73.9 \%, \tau^{2}=0.3314, \mathrm{p}<0.0001\right)$.

\section{Secondary Outcomes}


The secondary outcomes of prevalence of proteinuria and reduced renal function are also shown in Table 2. Forest plots are not depicted but weighted mean prevalence has been calculated below.

8 studies (509 children) reported the prevalence of proteinuria in children with ADPKD, all studies used an internationally accepted definition of proteinuria (urinary protein excretion $\geq 150 \mathrm{mg} /$ day or equivalent value for urine albumin to creatinine ratio or urine protein to creatinine ratio) and all measured this in the laboratory (rather than using bedside dipstick testing). The mean prevalence of proteinuria in children with ADPKD is $20 \%$ [95\% $\mathrm{Cl} 9-40 \%]$.

5 studies including 226 children reported the prevalence of reduced renal function in children with ADPKD, and this was defined as a GFR (actual or estimated) as $<90 \mathrm{ml} / \mathrm{min} / 1.73 \mathrm{~m}^{2}$. The mean prevalence of a reduced renal function in children with $\mathrm{ADPKD}$ is $8 \%[95 \% \mathrm{Cl} 2-26 \%]$.

\section{Additional Analyses}

Figure 2 shows the results from a meta-regression of prevalence of hypertension against the prevalence of proteinuria, there was no evidence of a relationship in this data (slope estimate $=-0.013[95 \% \mathrm{Cl}-0.04$ to 0.01$], p=0.2641$ ). Figure 3 shows the results from the meta-regression with mean age of children in a study as a covariate. The prevalence of hypertension increases as the mean age in the study increases (slope estimate $=0.13$ [95\% 0.03 to 0.22$], p=0.0128$ ). 


\section{Discussion}

This systematic review and meta-analysis estimated the mean prevalence of hypertension is $20 \%$ [ $95 \% \mathrm{Cl} 15-27 \%]$ from 928 children and young persons with ADPKD and 14 studies reported over the past two decades. Even when the studies with a high risk of selection bias were removed from the analysis, the same figure of $20 \%$ prevalence of hypertension was found. The pathophysiology of hypertension in ADPKD is complex and not fully understood,[8-10] but it is well-recognised that there can be hypertension in the absence of other signs such as proteinuria and reduced renal function. These observations were confirmed in children here - $20 \%$ had proteinuria but Figure 2 demonstrates the lack of a relationship with the prevalence of hypertension at study level. Unfortunately, individual patient data was not available from enough studies to investigate this further, but this is perhaps unsurprising given that the link between proteinuria and onset of renal dysfunction comes mainly from diffuse glomerular and tubulointerstital diseases, rather than the patchy cystic dilatation and expansion seen in ADPKD. Similarly, only $8 \%$ of children were reported to have reduced GFR.

One of the major criticisms of individual studies reporting the prevalence of hypertension in ADPKD is that they might reflect highly selected populations, derived from children referred to tertiary and specialist centres. These are likely to contain a higher proportion of symptomatic children and 'fast-progressors'. We recognise that some such reports are included in this meta-analysis but they were combined with all other available studies to generate the best current prevalence estimate at $20 \%$, with little change when data were reanalysed without three studies with a high risk of selection bias, which suggests that our concerns may be unfounded. 
There are limitations to this analysis, the most prominent being that none of the 14 included studies had the primary aim of reporting the prevalence of hypertension in children with ADPKD, therefore their study design was not optimised to estimate prevalence of hypertension in children with ADPKD. Although this reduces the risk of publication bias, it does mean that other biases would not have been accounted for in the original study designs. There was also a high degree of heterogeneity between the studies, which results in wide confidence and prediction intervals. In addition, we excluded several repeated studies from specific centres which clearly built up their cohort sizes over time but still included children that had been counted in earlier studies. There is a small risk, in excluding these studies, that we failed to include some children and therefore reduced our sample of studies. Furthermore, by using the mean as a best estimate of prevalence, we assume the samples of children with ADPKD in each study are representative of the population outside of a study setting.

Bearing in mind that two thirds of ADPKD patients are hypertensive by the age of 30 whereas we found $20 \%$ prevalence in children and young people, we performed further analysis from our studies to see if there appeared to be an increased risk with age (Figure 3). Using meta-regression we found that as the mean age in the study increased, the prevalence of hypertension increased. This is in agreement with adult knowledge where there is an increasing prevalence of hypertension with increasing age.

It is notable that only one of the included studies used ABPM to assess blood pressure in children. This is standard practice for diagnosing early hypertension in adults in many countries; in the UK, for example, the National Institute for Clinical Excellence 
(NICE) guidelines suggest that clinic BP levels around 140/90 should be confirmed by ABPM or regular home BP before starting therapy.[11] It could be argued that hypertension cannot be truly excluded through clinic BP measurement in children with ADPKD, ABPM measurement should be performed to exclude hypertension. This raises the possibility that our estimate of $20 \%$ is an underestimate because the included studies may have underdiagnosed 'borderline hypertension'. In the one study which performed ABPM for all 62 included children, 22 were deemed hypertensive in this study but out of these 10 children had isolated nocturnal hypertension which would not have been identified had ABPM not been used.[5] Therefore there is a risk that a large proportion of hypertensive children with ADPKD are not being identified under the current regimen and ABPM should be considered for future practice. In addition, a number of the studies included in our review note the increased risk of left ventricular hypertrophy in children with ADPKD which is clearly related to hypertension, and provides further evidence that hypertension in children with ADPKD can have significant health effects.[3], [12]

In conclusion, this systematic review and meta-analysis estimates a $20 \%$ prevalence of hypertension in children and young persons with ADPKD, calling into question the belief that some clinicians still hold about ADPKD being an 'adult' disease. In light of these results we recommend that all adults diagnosed with ADPKD should be asked about their children and offered advice and support in deciding on the medical management of their entire family. We also recommend that all children with confirmed ADPKD or are at risk of ADPKD should have annual blood pressure checks and urine albumin: creatinine ratio measurement to ensure timely diagnosis of any complications. Further prospective research is required to more carefully evaluate BP 
in children with $A D P K D$, including ABPM to detect 'borderline hypertension' and measures of target organ damage such as cardiac and vascular assessment to detect early complications of undiagnosed hypertension in children with ADPKD. The formation of ADPKD registries and the adoption of this condition to established registries such as the UK National Registry of rare kidney diseases (RaDaR) will hopefully facilitate further prospective multi-centre studies to investigate hypertension in children with ADPKD. 
"What is already known on this topic"

- $\quad$ ADPKD is a common disorder which often remains undiagnosed in childhood

- Children with ADPKD can develop hypertension

\section{"What this study adds"}

- Hypertension is common in ADPKD, affecting up to a quarter of children with ADPKD

- All children with confirmed ADPKD, or at risk of ADPKD, should have regular blood pressure monitoring during childhood

\section{Competing Interests:}

My co-authors and I declare no conflicts of interest.

\section{Funding:}

This study received no specific funding but was supported by the National Institute for Health Research Biomedical Research Centre at Great Ormond Street Hospital for Children NHS Foundation Trust and University College London. 


\section{References}

[1] V. E. Torres, P. C. Harris, and Y. Pirson, "Autosomal dominant polycystic kidney disease.," Lancet, vol. 369, no. 9569, pp. 1287-301, Apr. 2007.

[2] R. W. Schrier, K. Z. Abebe, R. D. Perrone, V. E. Torres, W. E. Braun, T. I. Steinman, F. T. Winklhofer, G. Brosnahan, P. G. Czarnecki, M. C. Hogan, D. C. Miskulin, F. F. RahbariOskoui, J. J. Grantham, P. C. Harris, M. F. Flessner, K. T. Bae, C. G. Moore, and A. B. Chapman, "Blood pressure in early autosomal dominant polycystic kidney disease.," New England Journal of Medicine, vol. 371, no. 24, pp. 2255-66, Dec. 2014.

[3] M. a Cadnapaphornchai, K. McFann, J. D. Strain, A. Masoumi, and R. W. Schrier, "Increased left ventricular mass in children with autosomal dominant polycystic kidney disease and borderline hypertension.," Kidney international, vol. 74, no. 9, pp. 1192-6, Nov. 2008.

[4] A. A. Shamshirsaz, A. Shamshirsaz, M. Reza Bekheirnia, R. M. Bekheirnia, M. Kamgar, A. M. Johnson, K. McFann, M. Cadnapaphornchai, N. Nobakhthaghighi, N. N. Haghighi, and R. W. Schrier, "Autosomal-dominant polycystic kidney disease in infancy and childhood: progression and outcome.," Kidney international, vol. 68, no. 5, pp. 2218-24, Nov. 2005.

[5] T. Seeman, J. Dusek, H. Vondrichová, M. Kyncl, U. John, J. Misselwitz, and J. Janda, "Ambulatory blood pressure correlates with renal volume and number of renal cysts in children with autosomal dominant polycystic kidney disease.," Blood pressure monitoring, vol. 8, no. 3, pp. 107-10, Jun. 2003.

[6] National High Blood Pressure Education Program Working Group on High Blood Pressure in Children and Adolescents., "The fourth report on the diagnosis, evaluation, and treatment of high blood pressure in children and adolescents.," Pediatrics, vol. 114, no. 2 Suppl 4th Report, pp. 555-76, Aug. 2004. 
[7] S. Sanderson, I. D. Tatt, and J. P. T. Higgins, "Tools for assessing quality and susceptibility to bias in observational studies in epidemiology: a systematic review and annotated bibliography.," International journal of epidemiology, vol. 36, no. 3, pp. 666-76, Jun. 2007.

[8] M. A. Cadnapaphornchai, "Hypertension in children with autosomal dominant polycystic kidney disease (ADPKD).," Current hypertension reviews, vol. 9, no. 1, pp. 21-6, Feb. 2013.

[9] I. Kocyigit, M. G. Kaya, O. Orscelik, C. Kaya, M. Akpek, H. Zengin, M. H. Sipahioglu, A. Unal, M. I. Yilmaz, B. Tokgoz, O. Oymak, and J. Axelsson, "Early arterial stiffness and inflammatory bio-markers in normotensive polycystic kidney disease patients.," American journal of nephrology, vol. 36, no. 1, pp. 11-8, Jan. 2012.

[10] I. Kocyigit, M. I. Yilmaz, A. Unal, F. Ozturk, E. Eroglu, C. Yazici, O. Orscelik, M. H. Sipahioglu, B. Tokgoz, and O. Oymak, "A link between the intrarenal renin angiotensin system and hypertension in autosomal dominant polycystic kidney disease.," American journal of nephrology, vol. 38, no. 3, pp. 218-25, Jan. 2013.

[11] T. Krause, K. Lovibond, M. Caulfield, T. McCormack, and B. Williams, "Management of hypertension: summary of NICE guidance.," BMJ (Clinical research ed.), vol. 343, p. d4891, Jan. 2011.

[12] D. D. Ivy, E. M. Shaffer, A. M. Johnson, W. J. Kimberling, A. Dobin, and P. A. Gabow, "Cardiovascular abnormalities in children with autosomal dominant polycystic kidney disease.," Journal of the American Society of Nephrology : JASN, vol. 5, no. 12, pp. 2032-6, Jun. 1995.

[13] O. Boyer, M.-F. Gagnadoux, G. Guest, N. Biebuyck, M. Charbit, R. Salomon, and P. Niaudet, "Prognosis of autosomal dominant polycystic kidney disease diagnosed in utero or at birth.," Pediatric nephrology (Berlin, Germany), vol. 22, no. 3, pp. 380-8, Mar. 2007.

[14] M. A. Cadnapaphornchai, D. M. George, K. McFann, W. Wang, B. Gitomer, J. D. Strain, and R. W. Schrier, "Effect of pravastatin on total kidney volume, left ventricular mass index, and microalbuminuria in pediatric autosomal dominant polycystic kidney disease.," Clinical journal of the American Society of Nephrology : CJASN, vol. 9, no. 5, pp. 889-96, May 2014. 
[15] K. Demetriou, C. Tziakouri, K. Anninou, A. Eleftheriou, M. Koptides, A. Nicolaou, C. C. Deltas, and A. Pierides, "Autosomal dominant polycystic kidney disease-type 2. Ultrasound, genetic and clinical correlations.," Nephrology, dialysis, transplantation : official publication of the European Dialysis and Transplant Association - European Renal Association, vol. 15, no. 2, pp. 205-11, Feb. 2000.

[16] F. Fencl, J. Janda, K. Bláhová, Z. Hríbal, J. Stekrová, A. Puchmajerová, and T. Seeman, "Genotype-phenotype correlation in children with autosomal dominant polycystic kidney disease.," Pediatric nephrology (Berlin, Germany), vol. 24, no. 5, pp. 983-9, May 2009.

[17] D. Mekahli, A. S. Woolf, and D. Bockenhauer, "Similar renal outcomes in children with ADPKD diagnosed by screening or presenting with symptoms.," Pediatric nephrology (Berlin, Germany), vol. 25, no. 11, pp. 2275-82, Nov. 2010.

[18] C. Nicolau, R. Torra, L. Bianchi, R. Vilana, R. Gilabert, A. Darnell, and C. Brú, "Abdominal sonographic study of autosomal dominant polycystic kidney disease.," Journal of clinical ultrasound: JCU, vol. 28, no. 6, pp. 277-82, 2000.

[19] B. Reed, E. Nobakht, S. Dadgar, M. R. Bekheirnia, A. Masoumi, F. Belibi, X. D. Yan, M. Cadnapaphornchai, and R. W. Schrier, "Renal ultrasonographic evaluation in children at risk of autosomal dominant polycystic kidney disease.," American journal of kidney diseases : the official journal of the National Kidney Foundation, vol. 56, no. 1, pp. 50-6, Jul. 2010.

[20] L. Selistre, V. de Souza, B. Ranchin, A. Hadj-Aissa, P. Cochat, and L. Dubourg, "Early renal abnormalities in children with postnatally diagnosed autosomal dominant polycystic kidney disease.," Pediatric nephrology (Berlin, Germany), vol. 27, no. 9, pp. 1589-93, Sep. 2012.

[21] J. B. Tee, P. D. Acott, D. H. McLellan, and J. F. S. Crocker, "Phenotypic heterogeneity in pediatric autosomal dominant polycystic kidney disease at first presentation: a single-center, 20-year review.," American journal of kidney diseases : the official journal of the National Kidney Foundation, vol. 43, no. 2, pp. 296-303, Feb. 2004. 
[22] H. Wong, L. Vivian, G. Weiler, and G. Filler, "Patients with autosomal dominant polycystic kidney disease hyperfiltrate early in their disease.," American journal of kidney diseases : the official journal of the National Kidney Foundation, vol. 43, no. 4, pp. 624-8, Apr. 2004. 


\section{Table 1}

Characteristics of 14 studies included in this systematic review.

\begin{tabular}{|c|c|c|c|c|}
\hline Study & $\begin{array}{l}\text { Mean } \\
\text { Age in } \\
\text { Study } \\
\text { (years) }\end{array}$ & Main Aim of Study & $\begin{array}{l}\text { Study } \\
\text { Design }\end{array}$ & Study Recruitment \\
\hline $\begin{array}{l}\text { Boyer et al. } \\
2007[13]\end{array}$ & 4.9 & $\begin{array}{l}\text { To study the prognosis of } \\
\text { children diagnosed with ADPKD } \\
\text { in-utero or at birth }\end{array}$ & $\begin{array}{l}\text { Retrospecti } \\
\text { ve cross- } \\
\text { sectional }\end{array}$ & $\begin{array}{l}\text { Consecutive recruitment of } \\
\text { selected group of children with } \\
\text { ADPKD }\end{array}$ \\
\hline $\begin{array}{l}\text { Cadnapaphornchai } \\
\text { et al. 2008[3] }\end{array}$ & 12.8 & $\begin{array}{l}\text { To assess the clinical } \\
\text { manifestations of ADPKD in } \\
\text { children, related to blood } \\
\text { pressure }\end{array}$ & $\begin{array}{l}\text { Prospective } \\
\text { observation } \\
\text { al }\end{array}$ & $\begin{array}{l}\text { Unclear, children with ADPKD } \\
\text { and normal renal function were } \\
\text { eligible }\end{array}$ \\
\hline $\begin{array}{l}\text { Cadnapaphornchai } \\
\text { et al. 2014[14] }\end{array}$ & 16 & $\begin{array}{l}\text { To assess the effect of } \\
\text { pravastatin on kidney structure } \\
\text { and size in children with ADPKD }\end{array}$ & $\begin{array}{l}\text { Randomise } \\
\text { d controlled } \\
\text { trial }\end{array}$ & $\begin{array}{l}\text { Unclear, all children in this study } \\
\text { were already receiving lisinopril }\end{array}$ \\
\hline $\begin{array}{l}\text { Demetriou et al. } \\
2000[15]\end{array}$ & $\begin{array}{l}\text { Not } \\
\text { reporte } \\
\text { d }\end{array}$ & $\begin{array}{l}\text { To assess disease and } \\
\text { symptoms in individuals with an } \\
\text { PKD2 mutation }\end{array}$ & $\begin{array}{l}\text { Prospective } \\
\text { observation } \\
\text { al }\end{array}$ & $\begin{array}{l}\text { knts recruited from } \\
\text { known to have the } \\
\text { utation }\end{array}$ \\
\hline $\begin{array}{l}\text { Fencl et al. } \\
2009[16]\end{array}$ & 8.7 & $\begin{array}{l}\text { To compare clinical features of } \\
\text { ADPKD in those with a PKD1 } \\
\text { and PKD2 mutation }\end{array}$ & $\begin{array}{l}\text { Retrospecti } \\
\text { ve cross- } \\
\text { sectional }\end{array}$ & $\begin{array}{l}\text { Retrospective, included all } \\
\text { children with a known PKD1 or } \\
\text { PKD2 mutation }\end{array}$ \\
\hline Ivy et al. 1995[12] & 9.6 & $\begin{array}{l}\text { To determine the cardiovascular } \\
\text { manifestations of ADPKD in } \\
\text { children }\end{array}$ & $\begin{array}{l}\text { Prospective } \\
\text { observation } \\
\text { al }\end{array}$ & $\begin{array}{l}\text { Children of parents with ADPKD } \\
\text { consecutively recruited, children } \\
\text { with confirmed ADPKD analysed }\end{array}$ \\
\hline $\begin{array}{l}\text { Mekahli et al. } \\
\text { 2010[17] }\end{array}$ & 12.9 & $\begin{array}{l}\text { To compare the manifestations } \\
\text { of ADPKD presenting by } \\
\text { screening or with symptoms }\end{array}$ & $\begin{array}{l}\text { Retrospecti } \\
\text { ve cross- } \\
\text { sectional }\end{array}$ & $\begin{array}{l}\text { Retrospective review of all } \\
\text { patients on a database with } \\
\text { ADPKD }\end{array}$ \\
\hline $\begin{array}{l}\text { Nicolau et al. } \\
2000[18]\end{array}$ & $\begin{array}{l}\text { Not } \\
\text { reporte } \\
\text { d }\end{array}$ & $\begin{array}{l}\text { To determine whether kidney } \\
\text { size is related to other } \\
\text { manifestations of ADPKD }\end{array}$ & $\begin{array}{l}\text { Prospective } \\
\text { observation } \\
\text { al }\end{array}$ & $\begin{array}{l}\text { Participants at risk of ADPKD } \\
\text { consecutively recruited, the } \\
\text { those with positive diagnosis } \\
\text { analysed }\end{array}$ \\
\hline $\begin{array}{l}\text { Reed et al. } \\
2010[19]\end{array}$ & $\begin{array}{l}\text { Not } \\
\text { reporte } \\
\text { d }\end{array}$ & $\begin{array}{l}\text { To update diagnostic criteria by } \\
\text { ultrasound for children with } \\
\text { ADPKD }\end{array}$ & $\begin{array}{l}\text { Retrospecti } \\
\text { ve cohort } \\
\text { study }\end{array}$ & $\begin{array}{l}\text { Retrospectively included all } \\
\text { children at risk of ADPKD, } \\
\text { confirmed diagnoses analysed }\end{array}$ \\
\hline $\begin{array}{l}\text { Seeman et al. } \\
\text { 2003[5] }\end{array}$ & 12.3 & $\begin{array}{l}\text { To determine if blood pressure } \\
\text { is related to kidney size in } \\
\text { ADPKD }\end{array}$ & $\begin{array}{l}\text { Prospective } \\
\text { observation } \\
\text { al }\end{array}$ & $\begin{array}{l}\text { Unclear whether consecutive } \\
\text { recruitment, children seen at } \\
\text { one centre }\end{array}$ \\
\hline $\begin{array}{l}\text { Selistre et al. } \\
\text { 2012[20] }\end{array}$ & 10 & $\begin{array}{l}\text { To evaluate the prevalence and } \\
\text { severity of early renal } \\
\text { dysfunction in ADPKD }\end{array}$ & $\begin{array}{l}\text { Prospective } \\
\text { observation } \\
\text { al }\end{array}$ & $\begin{array}{l}\text { All children with ADPKD referred } \\
\text { to one centre were } \\
\text { consecutively recruited }\end{array}$ \\
\hline $\begin{array}{l}\text { Shamshirsaz et al. } \\
\text { 2005[4] }\end{array}$ & 13.3 & $\begin{array}{l}\text { To determine the progression } \\
\text { and outcome of early onset } \\
\text { ADPKD in children }\end{array}$ & $\begin{array}{l}\text { Prospective } \\
\text { observation } \\
\text { al }\end{array}$ & $\begin{array}{l}\text { All children referred to a centre } \\
\text { or with parents with ADPKD } \\
\text { were consecutively recruited }\end{array}$ \\
\hline Tee et al. 2004[21] & 8.7 & $\begin{array}{l}\text { To determine the phenotypic } \\
\text { characteristics of ADPKD in } \\
\text { children }\end{array}$ & $\begin{array}{l}\text { Retrospecti } \\
\text { ve cross- } \\
\text { sectional }\end{array}$ & $\begin{array}{l}\text { All children seen at a single } \\
\text { centre over } 20 \text { years with } \\
\text { ADPKD }\end{array}$ \\
\hline $\begin{array}{l}\text { Wong et al. } \\
2004[22]\end{array}$ & 9.8 & $\begin{array}{l}\text { To assess the presence of } \\
\text { glomerular hyperfiltration in } \\
\text { children with ADPKD }\end{array}$ & $\begin{array}{l}\text { Prospective } \\
\text { observation } \\
\text { al }\end{array}$ & $\begin{array}{l}\text { All children with ADPKD but not } \\
\text { on therapy during a } 1 \text { year } \\
\text { period were eligible }\end{array}$ \\
\hline
\end{tabular}




\section{Table 2}

Outcome data for 14 studies included in this systematic review.

\begin{tabular}{|l|l|l|l|l|l|l|}
\hline Study & $\begin{array}{l}\text { Number of } \\
\text { children } \\
\text { that are } \\
\text { hypertensiv } \\
\text { e }\end{array}$ & $\begin{array}{l}\text { \% of } \\
\text { children } \\
\text { hypertensiv } \\
\text { e }\end{array}$ & $\begin{array}{l}\text { Number of } \\
\text { children } \\
\text { with } \\
\text { proteinuria }\end{array}$ & $\begin{array}{l}\text { \% of } \\
\text { children } \\
\text { with } \\
\text { proteinuria }\end{array}$ & $\begin{array}{l}\text { Number of } \\
\text { children } \\
\text { with } \\
\text { reduced } \\
\text { GFR }\end{array}$ & $\begin{array}{l}\% \text { of } \\
\text { children } \\
\text { with } \\
\text { reduced } \\
\text { GFR }\end{array}$ \\
\hline Boyer et al. 2007 & $5 / 26$ & $19 \%$ & $2 / 26$ & $8 \%$ & $2 / 26$ & $8 \%$ \\
\hline $\begin{array}{l}\text { Cadnapaphornchai } \\
\text { et al. 2008 }\end{array}$ & $28 / 85$ & $33 \%$ & & & & \\
\hline $\begin{array}{l}\text { Cadnapaphornchai } \\
\text { et al. 2014 }\end{array}$ & $40 / 110$ & $36 \%$ & & & & \\
\hline $\begin{array}{l}\text { Demetriou et al. } \\
\text { 2000 }\end{array}$ & $0 / 23$ & $0 \%$ & & & & \\
\hline Fencl et al. 2009 & $12 / 60$ & $22 \%$ & $24 / 50$ & $48 \%$ & $1 / 60$ & $2 \%$ \\
\hline Ivy et al. 1995 & $11 / 83$ & $13 \%$ & & & & \\
\hline Mekahli et al. 2010 & $7 / 47$ & $15 \%$ & $17 / 47$ & $36 \%$ & $13 / 33$ & $39 \%$ \\
\hline Nicolau et al. 2000 & $3 / 41$ & $7 \%$ & & & & \\
\hline Reed et al. 2010 & $15 / 67$ & $22 \%$ & & & & \\
\hline $\begin{array}{l}\text { Seeman et al. } \\
\text { 2003 }\end{array}$ & $22 / 62$ & $35 \%$ & $2 / 62$ & $3 \%$ & & \\
\hline Selistre et al. 2012 & $3 / 52$ & $6 \%$ & $30 / 52$ & $58 \%$ & $6 / 52$ & $12 \%$ \\
\hline $\begin{array}{l}\text { Shamshirsaz et al. } \\
\text { 2005 }\end{array}$ & $64 / 199$ & $32 \%$ & $73 / 199$ & $37 \%$ & & \\
\hline Tee et al. 2004 & $12 / 55$ & $22 \%$ & $4 / 55$ & $7 \%$ & $1 / 55$ & $2 \%$ \\
\hline Wong et al. 2004 & $0 / 18$ & $0 \%$ & $1 / 18$ & $6 \%$ & & \\
\hline
\end{tabular}

Hypertension - defined as blood pressure $>95^{\text {th }}$ centile for age and gender.

Reduced GFR (glomerular filtration rate) - defined as a GFR (estimated or measured) $<90 \mathrm{ml} / \mathrm{min}$. 


\section{Figure Legends}

\section{Figure 1}

Forest plot for the primary outcome of prevalence of hypertension in children with ADPKD, grouped according to risk of bias assessment.

\section{Figure 2}

Meta-regression graph showing prevalence of proteinuria vs. prevalence of hypertension across 8 studies reporting both outcomes (study-level data).

Footnotes to Figure 2:

Size of bubble corresponds to study size.

No evidence of a significant relationship $(p=0.26)$.

\section{Figure 3}

Meta-regression graph showing mean age vs. prevalence of hypertension across 11 studies reporting both (study-level data).

Footnotes to Figure 3:

Size of bubble corresponds to study size.

Prevalence of hypertension increases with mean age in the study $(p=0.01)$. 